ACTA THERIOLOGICA

Vol. 33, 32: 443-450, 1988

\title{
Sampling of Small Mammals by Different Types of Traps in Northern Ontario, Canada
}

\author{
Duncan G.L. INNES \& James F. BENDELL
}

Innes D.G.L. \& Bendell J.F. 1988; Sampling of small mammals by different types of traps in northern Ontario, Canada. Acta theriol,, 33, 32: 443-450. [With 3 Tables].

Previous studies have indicated that small mammal traps may not provide a random sample of all individuals in a population. Some types of traps may capture more species, more individuals or more of one sex than others. We examined the effectiveness of Longworth live-traps, Victor snap-traps, and plastic pot pitfall traps in catching small mammals in pure jack pine plantations. Live-traps caught more species than either snap- or pitfall traps, while snap-traps caught the most animals per 100 trap nights. Snap-traps captured heavier and longer individuals than pitfall traps in four species. Of four species caught in both snap- and pitfall traps, the only biased sex ratio was found in Sorex cinereus where significantly more males than females were caught. We suggest that the type(s) of traps used should depend on the question being asked and the time available for the study.

[Faculty of Dentistry, The University of Western Ontario, London, Ontario, Canada N6A 5C1 (D.G.L.I.); Faculty of Forestry, University of Toronto, Toronto, Ontario, Canada M5S 1A1 (J.F.B.)]

\section{INTRODUCTION}

A possible constraint on the censusing of small mammals is the type of trap used. Previous studies suggest that various kinds of traps can be biased in some way. One type of trap may catch more animals, more species, different size (age) classes or more of one sex than the other. For example, Howard \& Brock (1960); MacLeod \& Lethiecq (1963); Pucek (1969); Boonstra \& Krebs (1978); Pankakoski (1979); Pelikán et al. (1979) and Williams \& Braun (1983) all reported that pitfall traps captured more small mammals than conventional (i.e. commerical) live- or snap-traps. Pitfall traps also sampled more species than live- or snap-traps (Howard \& Brock, 1960; Williams \& Braun 1983). Boonstra \& Krebs (1978) found that pitfall traps sampled mostly young and transient Microtus townsendii (Bachman, 1939), while Longworth live-traps sampled almost exclusively resident adults $>40 \mathrm{~g}$. Most authors have concluded that pitfall traps sample shrews much better than conventional traps, while the reverse is true for rodents (e.g. Pankakoski, 1979; Williams \& Braun, 1983). , 
In a study designed to assess the impact of insecticide sprays for jack pine budworn Choristoneura pinus (Freeman, 1953) on non-target species, we were able to document the relative effectiveness of three types of small mammal traps: Longworth live-traps, Victor snap-traps, and plastic pitfall traps. We assessed each type of trap for the number of animals and species caught. We also tested for differences in body size and sex ratios between snap- and pitfall traps in four species.

\section{MATERIALS AND METHODS}

The study was conducted in jack pine (Pinus banksiana) plantations south of Gogama $\left(47^{\circ} 30^{\prime} \mathrm{N}, 81^{\circ} 40^{\prime} \mathrm{W}\right)$ in northern Ontario. Detailed habitat descriptions of the area can be found elsewhere (Naylor \& Bendell, 1983; Naylor et al., 1985). Briefly, the area is dominated by monospecific stands of jack pine ranging in age from two to over 40 years. These stands are the result of replanting after clear-cutting or wildfires. Common to these forests is a understory of blueberry (Vaccinium spp.), sheep laurel (Kalmia angustifolia), and sweetfern (Comptonia peregrina).

Live-, snap-, and pitfall trapping were conducted from early June to late August, 1985, in a variety of habitats (i.e. plantations of different ages). For a valid comparison among the different types of traps, trapping should be carried out in the same number of habitats because abundances and species composition will most likely vary with the habitat. Since the number of habitats sampled by each type of trap was not equal, we will consider here only those data that were collected in older jack pine plantations (38-40 years). (Most trapping was conducted in these older stands).

Four live-trap grids were established (each 4 by 10 , with $25 \mathrm{~m}$ between stations and one Longworth trap per station) approximately $1 \mathrm{~km}$ from each other. Traps were baited with carrots and sunflower seeds. Cotton mattress stuffing provided nesting material. Each grid was operated for one night, on average, every eight days (range: 5 to 10 days). Traps were locked open when not in use. At each capture, rodents were indentified to species, while shrews were recorded as Sorex spp. or Blarina brevicauda (Gapper, 1830). Rodents and B. brevicauda were individually marked and released. Sorex spp. were not marked because over $95 \%$ were found dead in the traps. These dead shrews were frozen and later indentified to species.

Victor mouse traps were set using lines of 25 stations (three traps per station and $20 \mathrm{~m}$ between stations) in a square U-shaped pattern. Each line was usually run for five nights and then moved to a new area. Traps were baited with a mixture of peanut butter and rolled oats. Traps were checked daily and specimens were frozen within $24 \mathrm{~h}$ of capture. Initially, we assumed that having three snap-traps per station would increase the probability of capturing many more animals than if only one snap-trap was set per station. This was not the case, because there were only 23 cases of double captures and two cases of triple captures. This represented $0.43 \%$ of all snap-trap nights. Therefore, for analysis of the snap-trap data, three traps were counted as only one snap-trap per station. 
Small mammals were also censused on four pitfall grids (each 5 by 10 , with $25 \mathrm{~m}$ between stations and one trap per station). Pitfall traps consisted of plastic pots $16 \mathrm{~cm}$ across and $12 \mathrm{~cm}$ deep. Each trap was half-filled with a $30 \%$ solution of ethyl alcohol and water. Traps were not baited, but the lip of each pot was placed flush with the forest floor. Traps were emptied of specimens and more preservative added (if necessary) approximately every seven days. Specimens were preserved in a $50 \%$ solution of ethyl alcohol and water.

Kill-trapped animals were identified by morphological and dental characteristics following Peterson (1966), Burt \& Grossenheider, and van Zyll de Jong (1983). Animals were sexed, weighed, and total length (tip of nose to tip of tail) taken. Frozen animals were thawed and weighed to the nearest $0.1 \mathrm{~g}$. Animals preserved in alcohol were weighed after excess liquid was absorbed by paper towels. One trap night (TN) refers to one trap set for one night.

\section{RESULTS}

A total of 12 species of small mammals were captured by a combination of all three types of traps (Table 1). These included four species of shrews and eight species of rodents. Live-traps caught the most species (10), pitfall traps the least (8), and snap-traps were intermediate (9). The proportions $(10 / 12,9 / 12,8 / 12)$ were not significantly different from one another $\left(\chi^{2}=0.89, p>0.05\right)$. However, both snap- and pitfall traps failed to capture the two biggest species Eutamias minimus

Table 1

Number of small mammals caught per 100 trap nights (TN) by Longworth live-traps, Victor snap-traps and plastic pitfall traps in pure jack pine forests.

\begin{tabular}{lccc}
\hline \multicolumn{1}{c}{ Species } & \multicolumn{2}{c}{ Trap type } \\
\cline { 2 - 3 } & Live-traps & Snap-traps & Pitfall traps \\
\hline Shrews & & & \\
Blarina brevicauda & 1.95 & 2.14 & 0.13 \\
Sorex cinereus & 4.33 & 8.15 & 7.11 \\
S. fumeus & 0.04 & 0.33 & 0.13 \\
S. hoyii & 0.00 & 0.00 & 0.32 \\
Rodents & & & \\
Clethrionomys gapperi & 1.04 & 2.72 & 0.04 \\
Eutamias minimus & 0.08 & 0.00 & 0.00 \\
Microtus chrotorrhinus & 0.08 & 0.17 & 0.01 \\
Napeozapus insignis & 0.29 & 0.49 & 0.00 \\
Peromyscus maniculatus & 1.29 & 1.65 & 0.01 \\
Phenacomys intermedius & 0.96 & 0.74 & 0.38 \\
Tamias striatus & 0.04 & 0.00 & 0.00 \\
Zapus hudsonicus & 0.00 & 0.08 & 0.00 \\
N of species & 10 & 9 & 8 \\
N of TN & 2,400 & 1,215 & 15,963 \\
N/100 TN & 10.10 & 16.47 & 8.13 \\
\hline
\end{tabular}


(Allen, 1890) and Tamias striatus (Richardson, 1829), while the smallest species S. hoyii (Baird, 1858) was not sampled by either live- or snap-traps. The two species of zapodids (Napeozapus insignis (Preble, 1899) and Zapus hudsonicus (Davies, 1798)) were not captured by pitfall traps, while all other medium sized rodents were captured to some degree by all three types of traps. Similarly, the larger species of shrews were captured to some degree by all three types of traps.

If trap efficiency is defined as the total number of animals caught per $100 \mathrm{TN}$, then the most efficient trap was the snap-trap followed by the live-trap and then the pitfall trap (Table 1). A oneway analysis of variance (with the number of grids or lines as replicates) showed no significant difference in the number of animals caught per $100 \mathrm{TN}$ among the types of traps $(F=3.14, p>0.05)$. Overall, the total number of animals was greatly influenced by the large number of $S$. cinereus (Kerr, 1792) captured. To a degree, snap-traps caught more animals relative to the other types of traps because of high numbers of Clethrionomys gapperi (Vigors, 1830) and Peromyscus maniculatus (Le Conte, 1855).

Four species (B. brevicauda, C. gapperi, Phenaeomys intermedius (Merriam, 1889) and $S$. cinereus) were captured in sufficiently large numbers $(\mathrm{N}>10)$ to test for differences in body weight, body length and sex ratios between snap- and pitfall traps. Snap-traps caught significantly larger animals (by weight and by length than pitfall traps in all four species (Table 2). The maximum difference in weight occurred in C. gapperi $(7.9 \mathrm{~g})$, while the maximum difference in length occurred in $P$. intermedius $(19.3 \mathrm{~mm})$. Of the four species, there was a significant sex

Table 2

Mean weights $(\mathrm{g})$ and total lengths $(\mathrm{mm})( \pm 1 \mathrm{SE})$ of four species of small mammals captured by snap- and pitfall traps in pure jack pine forests.

\begin{tabular}{|c|c|c|c|c|c|c|}
\hline \multirow[t]{2}{*}{ Species } & \multicolumn{2}{|c|}{ Snap-traps } & \multicolumn{2}{|c|}{ Pitfall traps } & \multirow[t]{2}{*}{$t$} & \multirow[t]{2}{*}{$p$-value } \\
\hline & $\mathrm{n}$ & $\bar{x} \pm \mathrm{SE}$ & $\mathrm{n}$ & $\bar{x} \pm \mathrm{SE}$ & & \\
\hline \multicolumn{7}{|c|}{ Weight } \\
\hline B. brevicauda & 41 & $17.6 \pm 0.3$ & 23 & $13.7 \pm 0.7$ & 4.18 & $<0.001$ \\
\hline C. gapperi & 52 & $18.6 \pm 0.5$ & 11 & $10.7 \pm 0.6$ & 3.15 & $<0.001$ \\
\hline P. intermedius & 39 & $17.7 \pm 1.6$ & 71 & $10.8 \pm 0.4$ & 5.45 & $<0.001$ \\
\hline$S$. cinereus & 175 & $3.9 \pm 0.1$ & 1399 & $3.5 \pm 0.1$ & 5.67 & $<0.001$ \\
\hline \multicolumn{7}{|c|}{ Length } \\
\hline B. brevicauda & 41 & $122.0 \pm 0.7$ & 23 & $117.9 \pm 1.3$ & 2.99 & $<0.01$ \\
\hline C. gapperi & 52 & $126.0 \pm 2.8$ & 11 & $109.8 \pm 6.0$ & 4.46 & $<0.001$ \\
\hline P. intermedius & 39 & $116.2 \pm 10.4$ & 71 & $96.9 \pm 1.3$ & 6.75 & $<0.001$ \\
\hline$S$. cinereus & 175 & $99.7 \pm 0.4$ & 1425 & $94.0 \pm 0.1$ & 13.13 & $<0.001$ \\
\hline
\end{tabular}


ratio bias only in $S$. cinereus from the pitfall traps with more males captured (Table 3). A reverse, but non-significant bias towards female $S$. cinereus was shown by snap-trap captures.

Table 3

Sex ratios ( $\%$ females) of four species of small mammals captured by snap- and pitfall traps in pure jack pine forests.

\begin{tabular}{|c|c|c|c|c|c|c|}
\hline \multirow{2}{*}{ Species } & \multicolumn{3}{|c|}{ Snap-traps } & \multicolumn{3}{|c|}{ Pitfall traps } \\
\hline & Females & Males & Ratio $(\%)$ & Females & Males & Ratio $(\%)$ \\
\hline B. brevicauda & 25 & 16 & 61.0 & 14 & 9 & 60.9 \\
\hline C. gapperi & 23 & 29 & 44.3 & 7 & 4 & 63.6 \\
\hline P. intermedius & 25 & 14 & 64.1 & 37 & 35 & 51.4 \\
\hline$S$. cinereus & 100 & 75 & 57.0 & 659 & 766 & $46.2^{1}$ \\
\hline
\end{tabular}

${ }^{1}$ Significantly different from $1: 1 ; \chi^{2}=4.02, p<0.05$.

\section{DISCUSSION}

Our data generally confirm previous studies that found that traps do not necessarily capture a random sample of small mammals. However, we found that pitfall traps do not necessarily catch more species than conventional traps, as found by others (e.g. Williams \& Braun, 1983). Pitfall traps caught the fewest species presumably because they were too narrow and shallow to capture the two largest species, E. minimus and T. striatus, while live- and snap-traps caught them in low numbers. Similarly, no zapodids were caught in pitfall traps presumably because they could either avoid falling into them or get out once they had fallen in. Wider and deeper pitfall traps $(23.5 \times 22.5 \mathrm{~cm}$, respectively; Williams \& Braun, 1983) captured many zapodids relative to the ones used in this study. S. hoyii was not sampled by live- and snap-traps. Perhaps because of their small size they can enter Longworth live-traps and not set them off by going under the treadle bar. Similarly, they may not be heavy enough to set off Victor snap-traps. These types of size biases have been noted before. Martell (1979) reported that larger snap-traps (Museum Specials) caught more species than smaller snap-trap (Victors). Therefore, both the dimensions of a pitfall trap and the kind or size of the conventional trap it is compared to will influence conclusions regarding which trap captures more species.

Pitfall traps did not capture more small mammals or shrews more 
efficiently than the conventional traps, as found by others (e.g. Pucek, 1969; Pankakoski, 1979). Although, we found no statistical difference among the types of traps, snap-traps captured the most small mammals and shrews per $100 \mathrm{TN}$. The differences are probably the result of two factors. First, the methodology involved with each type of trap was different. Pitfall traps were used as continuous removal traps over localized areas. Live-traps, although intended to be used for mark-recapture, acted more like removal traps, because most shrews were found dead and rodents that were marked were rarely recaptured during most of the season (Innes \& Bendell, in prep.). Snap-traps removed animals from a localized area but for only a short period. Thus, snap-traps sampled areas not depleted of animals from previous trapping, while both live- and pitfall catches would be influenced by previous sampling. Therefore, snap-traps should capture more animals than the other two types of traps. Second, this difference may also be due to the dimensions of our pitfall traps. Pankakoski (1979) found that deeper pitfall traps $(35 \mathrm{~cm})$ captured more animals per $100 \mathrm{TN}$ than shallower ones $(25 \mathrm{~cm})$. Of the 12 species captured in this study, only $S$. hoyii was sampled more efficiently by pitfall traps than the other two, but overall they were the least efficient trap.

Snap-traps captured larger individuals than pitfall traps, as found by Pelikán et al. (1977) and Pankakoski (1979). This suggests that either larger individuals (adults) can get out of or avoid pitfall traps more readily than smaller individuals (juveniles). Boonstra \& Krebs (1978) found that live-traps captured adults much more readily than pitfall traps. They suggested that the odour left by dominant adults in the live-traps inhibited juveniles from entering them.

Only $S$. cinereus captured in the pitfall traps showed a significant sex ratio bias. This resulted from fewer adult females being caught compared to adult males and juveniles of both sexes (unpublished data). Since pitfall traps functioned as continuous removal traps it is likely that they would capture dispersing individuals after the residents were removed. It maybe that adult $S$. cinereus females are less likely to disperse than the other sex/age groups, perhaps connected to the energetic demands of gestation and lactation.

The type of trap as well as the trapping methodology should be selected by an investigator with reference to answering a particular question. For example, to get a complete census of all 12 species in our area both live- and pitfall traps would be needed because T. striatus was sampled only by live-traps and $S$. hoyii was sampled only by pitfall traps. Snap-traps did not capture either species. To maximize the number of animals captured per $100 \mathrm{TN}$, only snap-traps (moved 
on a regular basis) should have been used. If data were required only on the two smallest shrews ( $S$. cinereus and $S$. hoyii), only pitfall traps should have been set. Alternatively, if only a limited amount of time was available, pitfall traps used as kill-traps should have been used because they require little maintenance and do not need to be checked as frequently as conventional traps.

Acknowledgements: We thank B. Naylor and K. Szuba for their advice, help, and interest in the study. We are appreciative of the excellent technical assistance of J. Barton. B. Smith is thanked for separating the mammals from the insects in the pitfall samples. We acknowledge the administrative support of U. Cattelan and staff. J.S. Millar and the small mammal ecology group, Department of Zoology, University of Western Ontario, gave helpful criticism on earlier drafts of this paper. Financial support was provided by N.S.E.R.C., C.F.S., and Federal manpower programs to J.F.B.

\section{REFERENCES}

1. Boonstra R. \& Krebs C.J., 1978: Pitfall trapping of Microtus townsendii. J. Mamm., 59: 136-148.

2. Burt W.H. \& Grossenheider R.P., 1976: A field guide to the mammals. Houghton Mifflin Co.: 1-289, Boston.

3. Howard W.E. \& Brock E.M., 1961: A drift-fence pit trap that preserves captured rodents. J. Mamm,, 42: 386-391.

4. MacLeod C.F. \& Lethiecq J.L., 1963: A comparison of two trapping procedures for Sorex cinereus. J. Mamm., 44: 277-278.

5. Martell A.M., 1979: Relative efficiencies of Museum Special, Victor, and Holdfast traps for sampling small mammal populations. Can. Field-Nat., 93: $313-315$.

6. Naylor B.J. \& Bendell J.F., 1983: Influence of habitat diversity on the abundance and diversity of small mammals in Jack Pine forests in Ontario. [In: "Resources and dynamics of the boreal zone". R.W. Wein, R.R. Riewe \& I R. Methven, eds.] Assn. Canadian Univ. Northern Studies: 295-307, Ottawa.

7. Naylor B.J., Bendell J.F. \& Spires S., 1985: High density of Heather Voles, Phenacomys intermedius, in Jack Pine, Pinus banksiana, Forests in Ontario. Can. Field-Nat., 99: 494-497.

8. Pankakoski E., 1979: The cone trap- A useful tool for index trapping of small mammals. Ann. Zool. Fennici, 16: 144-150.

9. Pelikán J., Zejda J. \& Holišova V., 1977: Efficiency of different traps in catching small mammals. Folia Zool., 26: 1-13.

10. Peterson R.L., 1966: The mammals of Eastern Canada. Oxford Univ. Press: 1-465. Toronto.

11. Pucek Z., 1969: Trap response and estimation of numbers of shrews in removal catches. Acta theriol., 14: 403-426.

12. van Zyll de Jong C.G., 1983: Handbook of Canadian mammals. National Museum of Canada: 1-210. Ottawa.

13. Williams D.F. \& Braun S.E., 1983. Comparison of pitfall and conventional traps for sampling small mammal populations. J. Wildl. Manage., 47: 841-845.

Received 14 January 1988, Accepted 20 Febraury 1988. 
Duncan G. L. INNES i James F. BENDELL

\section{ŁOWIENIE SSAKOW W ROZNE TYPY PUŁAPEK W POLNOCNYM ONTARIO}

Streszczenie

Poprzednie badania wskazywały, że używanie pułapek na male gryzonie może nie dostarczać losowej próby osobników z populacji. Niektóre typy pułapek mogą lapać więcej gatunków, więcej osobników lub więcej przedstawicieli jednej płci niż inne typy.

Sprawdzono efektywność wyłowu gryzoni przez żywolówki typu Longworth, zatrzaski typu Victor oraz plastikowe kubły stosowane tak jak stożki. Odlowy prowadzone byly w czystym borze sosnowym (Pinus banksiana).

Najwięcej różnych gatunków lapały żywiołówki, natomiast zatrzaski lapały największą liczbę osobników na 100 pułapkonocy (Tabela 1). W przypadku czterech gatunków zatrzaski łapały cięższe i większe osobniki niż kubły (Tabela 2). Z czterech gatunków lapanych zarówno przez zatrzaski jak i kubły, tylko u Sorex cinereus Kerr, 1792 stwierdzono zmieniony stosunek płci: złapało się istotnie więcej samców niż samic (Tabela 3). Sugeruje się, że rodzaj pułapki powinien byč dobierany $w$ zależności od celu badań oraz czasu przeznaczonego na odłowy. 